NBER WORKING PAPER SERIES

\title{
FINANCIAL RESTRUCTURING IN BANKING AND CORPORATE SECTOR CRISES: WHAT POLICIES TO PURSUE?
}

\author{
Stijn Claessens \\ Daniela Klingebiel \\ Luc Laeven \\ Working Paper 8386 \\ http://www.nber.org/papers/w8386 \\ NATIONAL BUREAU OF ECONOMIC RESEARCH \\ 1050 Massachusetts Avenue \\ Cambridge, MA 02138 \\ July 2001
}

The authors are at the World Bank, the University of Amsterdam and CEPR, the World Bank, and the World Bank, respectively. The paper was presented at the NBER-conference on Management of Currency Crises, held in Monterey, March 28-31, 2001. We would like to thank Peter Kenen, Jeffrey Frankel and other participants at the conference for very helpful comments. We thank Ying Lin for help with the data. The views expressed herein are those of the authors and not necessarily those of the National Bureau of Economic Research or The World Bank.

(C) 2001 by Stijn Claessens, Daniela Klingebiel and Luc Laeven. All rights reserved. Short sections of text, not to exceed two paragraphs, may be quoted without explicit permission provided that full credit, including (C) notice, is given to the source. 
Financial Restructuring in Banking and Corporate Sector Crises:

What Policies to Pursue?

Stijn Claessens, Daniela Klingebiel and Luc Laeven

NBER Working Paper No. 8386

July 2001

JEL No. G18, G21, G28, E53, E58, F33, F36

\begin{abstract}
We review the literature on resolving bank and corporate sector crises to identify government policies that affect the depth of a crisis and the ease and sustainability of recovery, and to analyze their fiscal cost. A consistent framework - including sufficient resources for loss-absorption and private agents facing the right framework of sticks and carrots - is the, although often missing key to successful bank and corporate restructuring. Sustainability of restructuring calls for deeper structural reforms, which often requires dealing with political economy factors up-front. Using data for 687 corporations from eight crisis countries, we find empirically that a package of specific resolution measures can help accelerate the recovery from a crisis. These policies, however, come with significant fiscal costs.
\end{abstract}

Stijn Claessens

Finance Group University of Amsterdam

Roetersstraat 11

1018 WB Amsterdam

The Netherlands

stijn@,fee.uva.nl
Daniela Klingebiel Financial Sector Strategy and Policy

World Bank

1818 H Street NW

Washington, DC 20433

Dklingebiel@,worldbank.org
Luc Laeven

Financial Sector Strategy and Policy World Bank 1818 H Street NW

Washington, DC 20433

LLaeven@worldbank.org 


\section{Introduction}

Whether cause or effect, a systemic banking and corporate sector crisis is often part of a currency crisis. ${ }^{1}$ The resolution of a banking and corporate sector crisis involves many policy choices ranging from macro-economic, including the tightness of monetary and fiscal policy, to micro-economic, including capital adequacy rules and corporate governance requirements, and varying in depth of fundamental reforms. These choices involve various tradeoffs, including the speed of recovery and its ultimate sustainability, and the magnitude of fiscal resources needed to resolve the crisis. In spite of much analysis, the tradeoffs along these dimensions are still not well known, leading at times to conflicting policy advice and possibly larger than necessary economic costs. And even less known are the political economy factors that make governments choose certain policy paths.

This paper reviews the current knowledge on the various tradeoffs regarding public policies towards systemic financial and corporate sector restructuring. It finds that consistency in the framework adopted for bank and corporate restructuring is the key factor for success, although often missing. This consistency covers many dimensions and entails, among others, ensuring that there are sufficient resources for loss-absorption and that private agents face an appropriate framework of sticks and carrots for restructuring. To assure the sustainability of restructuring, deeper structural reforms will be necessary, which often will require that political economy factors are considered up-front.

The paper complements the literature review with some new empirical analysis using data for 687 corporations from eight crisis countries. It investigates the quantitative importance of some specific government policies: liquidity support to financial institutions, the guaranteeing of the liabilities of the financial system during the early phase of the crisis, and the establishment of a public asset management company during the restructuring phase. It finds that a package of these measures can facilitate quicker recovery by the corporate sector from a crisis and assist in the sustainability of the recovery. The particular policies come with large fiscal costs, however, leading to tradeoffs in terms of an equitable distribution of the benefits and cost of the government intervention and, possibly in terms of the ultimate growth impact.

The paper proceeds as follows. Section 2 presents an overview of the general characteristics of banking system and corporate sector crises. Section 3 reviews the literature on banking and corporate sector crises. Section 4 provides empirical evidence on the effects of crisis resolution policies using firm-level data from a set of crisis countries. Section 5 concludes.

\footnotetext{
${ }^{1}$ The word systemic is used here to refer to a crisis that is large relative to a national economy, not necessarily large relative to the global economy or a crisis that has other global spillovers.
} 


\section{Characteristics of banking system and corporate sector crises}

A systemic banking system and corporate sector crisis can be characterized as a situation where an economy faces within a short period of time large-scale corporate and financial distress. ${ }^{2}$ Examples of recent crises include the Nordic countries' crises in the early 1990s, the Mexico crisis in 1994/5, the crises in East Asian countries after 1997, and some crises in transition economies in the 1990s (although for the latter economies, financial distress and structural problems had been longer-term phenomena). The frequency of banking and corporate sector crises appears to have increased since the early 1980s. Caprio and Klingebiel (1999) identified 93 countries that experienced a systemic financial crisis during the 1980s or 1990s (Figure 1). It also appears that the depth of crises has increased in the 1990s compared to earlier periods (Bordo, et al., 2001). Furthermore, most of the recent crises were in developing countries: of the 93 cases, only five were in developed countries.

Typically in a systemic crisis, in part as a result of large shocks to foreign exchange and interest rates, and a general economic slowdown, the corporate and financial sectors will experience a large number of defaults and difficulties to repay contracts on time and non-performing loans will increase sharply. This situation is often accompanied by generally depressed asset prices, such as equity and real estate prices, following typical run ups before the crisis, sharp real interest rate increases, and a slowdown of or reversal in capital flows. In countries with longer-term financial distress and other structural problems that reached (too) large proportions, such as several transition economies, a systemic crisis may not be accompanied by the same asset price and capital flows behavior, in part as the run ups in prices and capital flows may not have occurred. Table 1 presents some key variables for a sample of systemic crisis countries for which we undertake some further empirical work in this paper. The table confirms the general characteristics of systemic crises.

The pattern of these crises highlights the complicated coordination problems that arise among individual corporations, between the corporate and financial sectors, between the government and the rest of the economy, and with respect to domestic and foreign investors. In a systemic crisis, an individual corporation's fate, and its owners' and managers' best course of actions, will depend on the actions of many other corporations and financial institutions, and the general economic outlook. The financial and the corporate sectors, always already very closely intertwined, will need both restructuring in a systemic crisis, with actions affecting each other's liquidity and solvency situation. The government will need to set both the rules of the game as well as be a main actor in the restructuring. And investors, domestic and foreign, will await the signs of actions of owners, government, labor and others, often implying a shortage of foreign and domestic capital when needed most.

\footnotetext{
${ }^{2}$ We do not focus on trying to identify the exact causes of systemic distress, not on whether currency crises are caused by systemic financial distress in the banking system and corporate sector or vice-versa. See further papers in Edwards and Frankel (eds.), forthcoming.
} 
The crisis and its coordination problems are typically aggravated by institutional weaknesses, many of which likely gave rise to the crisis in the first place. There will often be deficiencies in the bankruptcy and restructuring frameworks; disclosure and accounting rules for financial institutions and corporations may be weak; equity and creditor rights might be poorly defined; the judicial efficiency will often be limited; etc.. There will typically also be a shortage of qualified management in the corporate and financial sectors, and a lack of qualified domestic restructuring and insolvency specialists, in part, as there may not have been a history of corporate and financial sector restructuring. The government itself may face credibility problems, as it was possibly part of the cause of the crisis, and in general faces many time-consistency problems, e.g., how to avoid large bailouts while at the same time restarting the economy.

These complicated coordination problems already suggest that a systemic crisis will be difficult to resolve. Many observers have tried to develop best practice lessons on how to best resolve a systemic crisis. We next review this literature.

\section{Review of literature}

Governments have used a variety of approaches to try to resolve systemic bank and corporate distress. Resolving systemic financial distress is no easy task and opinions as what constitutes best practice appear to differ widely. Many different and what appears to be at times contradictory, policy recommendations have been made to limit the fiscal cost of crises and speed up the recovery. Empirical research supporting particular views in this area remains limited, and most research is limited to particular, individual cases. Sheng (1996) was the first attempt to distill lessons from a review of several banking crises. Caprio and Klingebiel (1996) expanded on these lessons using some additional case studies. The main lesson of these two studies is that managing a financial crisis in a developed country differs significantly from that in emerging market economies given their poorer institutional environment, the often larger size of crises and other initial differences. As a result, "best practice" lessons from developed countries do not translate easily to developing countries. Another key lesson is that there will be tradeoffs in many dimensions between the various policies.

In reviewing the literature on financial restructuring, especially as it applies to emerging markets, it is useful to differentiate between three aspects of systemic financial restructuring. During the first phase, which can be called the short-term containment phase, the financial crisis is still unfolding. Governments tend to implement policy measures in this phase that are mostly aimed at restoring overall public confidence to minimize the repercussions of the loss of confidence by depositors and other investors in the financial system on the real sector. The second phase comprises the actual financial, and to a lesser extent, operational restructuring of financial institutions and corporations. The third phase refers to structural reforms, including changes in the legal and regulatory frameworks, privatization of any nationalized financial institutions and corporations, etc. Of these phases, we discuss the containment phase and the restructuring of financial institutions and corporations separately. 


\section{A. Containment phase}

Policymakers often fail to respond effectively to any evidence of an impending banking crisis, hoping that banks and corporations will grow out of their problems. ${ }^{3}$ Rather than waiting, intervening early with a comprehensive and credible plan can avoid a systemic crisis, minimize adverse effects, and limit the overall losses (Sheng 1996). Early intervention appears especially important in stopping the flow of financing to lossmaking financial institutions and corporations and to limit moral hazard of financial institutions and corporations gambling for survival. Experience further suggests that the intervention and closure processes for weak financial institutions need to be properly managed. Uncertainty among depositors needs to be limited, as otherwise government may have to try to resolve a loss of confidence with an unlimited government guarantee on banks' and other financial institutions' liabilities. In practice, however, ad hoc closures are more the norm and often add to the overall uncertainty, and thereby trigger a systemic crisis. For example, the closure of a group of 16 banks in Indonesia in late 1997 triggered a depositor run, as depositors were aware of the fact that some politically, wellconnected banks known to be insolvent were kept open (Lindgren et al. 2000). Similarly, the suspension of finance companies in Thailand led to further uncertainty among depositors as well as borrowers.

Reviewing several cases, Baer and Klingebiel (1995) suggest that, to avoid uncertainty among depositors and limit depositors' incentives to run, policymakers need to deal simultaneously with all insolvent and marginally solvent institutions. Intermittent regulatory intervention increases depositors' nervousness and damages regulatory credibility, especially in cases where regulators had previously argued that the institutions were solvent. ${ }^{4}$ In emerging markets, moreover, given the often-weak regulatory environment, limited supervisory resources, and poor data indicators for financial (in-) solvency, intervention tools need to be designed in a relatively simple way. For example, a rehabilitation program for undercapitalized financial institutions, which involves institutions indicating how they plan to meet capital adequacy requirements in the future, requires careful government oversight and good quality financial statements, often not present in developing countries. Instead of relying on rehabilitation with the need for good oversight and data, regulators could instead apply a 100 percent (marginal) reserve requirement on deposit inflows and other new liabilities, thus limiting the ability of weak banks to reallocate resources in any detrimental way.

\footnotetext{
${ }^{3}$ We acknowledge that there will be many political economy reasons why policy makers may not wish to act, thereby giving rise to the crisis in the first place, but do not discuss these here (see further papers in Edwards and Frankel (eds.), and also Haggard, 2001).

${ }^{4}$ They also point out that a comprehensive approach presents the additional advantage of reducing the demand on supervisory resources. Under a piecemeal approach, insolvent and marginally solvent institutions would continue to exist at the same time that other insolvent were being closed or restructured. These marginally solvent institutions would be subject to moral hazard and fraud, while unable and unwilling to raise additional capital. Especially in an environment with weak supervisory resources, comprehensive approaches are thus more necessary.
} 
There appear to be two schools of thoughts on whether to employ liquidity support and unlimited guarantees during the containment phase. ${ }^{5}$ Some argue that crisis conditions make it all but impossible to distinguish between solvent and insolvent institutions, leaving the authorities with little option but to extend liquidity support. Moreover, it is argued that the issuance of an unlimited guarantee preserves the payments system and helps stabilize institutions' financial claims while the restructuring work is being organized and carried out (Lindgren et al. 2000). Others argue that open-ended liquidity support provides more time for insolvent institutions to gamble (unsuccessfully) for resurrection, facilitates the continued flow of financing to loss-making borrowers, and allows owners and managers to engage in looting. And they argue that a government guarantee on financial institutions' liabilities reduces (large) creditors' incentives to monitor financial institutions, thus allowing bank managers and shareholders to continue "gambling to resurrect" their insolvent banks, and increasing the overall fiscal costs. They further point out that extensive guarantees limit the governments' maneuverability in terms of how to allocate losses, with often the end result that the government incurs most of the cost of the systemic crisis (Sheng 1996).

In practice, there will be a tradeoff between re-establishing confidence and fiscal costs. Some evidence on these tradeoffs comes from Honohan and Klingebiel (2000). They show that a large part of the variation in the fiscal cost of 40 crises in industrial and developing economies (1980-97) can be explained by different government approaches to resolving their liquidity crises. They find that governments that used open-ended liquidity support and blanket deposit guarantees substantially increased the overall fiscal costs of resolving a financial crisis. They also find that these costs are larger in weaker institutional settings. Most importantly, they find no obvious tradeoff between fiscal costs and subsequent economic growth recovery (or overall output losses). Countries that employed policy measures such as liquidity support, blanket guarantees or forbearance policies that were particularly costly to the budget did not recover faster subsequently. Rather, they find that the extension of liquidity support appears to make recovery from a crisis longer and output losses larger. This latter finding is confirmed by Bordo et al. (2001). This suggests that the two most important policies during the initial containment phase are to limit liquidity support and not to extend guarantees. It also suggests that in weaker institutional settings, governments may need to use relatively simple methods in dealing with weak banks and loss of confidence to avoid increases in fiscal contingencies and costs.

\footnotetext{
${ }^{5}$ A third school may argue that the granting of government guarantees is the outcome of political economy circumstances, and often thus a foregone conclusion. See also Dooley (in this volume).
} 


\section{B. Restructuring and rehabilitating financial institutions}

Following the phase of stabilizing financial markets, the second phase involves the restructuring of weak financial institutions and corporations. The restructuring phase is a complex undertaking, as policymakers need to take into account various aspects. Importantly, financial restructuring will depend on the speed at which macro-stability can be achieved since this will determine the viability of corporations, banks and other financial institutions, and more general the reduction in overall uncertainty. Yet, macro stability will often require progress in financial and corporate restructuring, and can thus not be seen independently from the restructuring process (see further, for example, Eichenbaum, Rebelo and Burnside, and Park and Lee in this conference volume).

Restructuring refers to several related processes: recognizing and allocating financial losses; restructuring financial claims of financial institutions and corporations; and operational restructuring of financial institutions and corporations. Recognition involves the allocation of existing losses and associated redistribution of wealth and control. Losses, that is differences between financial institutions' and corporations' market value of assets and nominal values of liabilities, can be allocated to shareholders - by dilution, to depositors and external creditors - by reduction of (the present value) of their claims, to employees - by reduced wages and suppliers, and to the government, that is the public at large-through increased taxes, expenditures cuts or inflation. We discuss here the restructuring of financial institutions and in the next section the restructuring of corporations.

To minimize moral hazard and strengthen financial discipline, the government can allocate losses not only to existing shareholders, but also to creditors and (large) depositors who should have monitored the bank. Often, however, the government will assume all losses through its guarantees. Nevertheless, there are exceptions to the model of governments guaranteeing all liabilities in attempts to restore confidence. Baer and Klingebiel (1995) show that in some crises, most notably the United States (1933), Japan (1946), Argentina (1980-82), and Estonia (1992), governments imposed losses on depositors with little (or no) adverse macro-economic consequences or flight to currency. Economic recovery in the cases where government imposed losses on depositors was rapid and financial intermediation, including household deposits, was restored within a short time. Allocating losses to creditors or depositors will thus not necessarily lead to runs on banks or end in contraction of aggregate money and credit, and output. Relatedly, Caprio and Klingebiel (1996) show that financial discipline is further strengthened when bank management, often part of the problem, is changed as well, and banks are operationally restructured.

Besides direct allocation of losses, the processes of financial sector and corporate restructuring, intrinsically linked with one another, crucially depend on the incentive frameworks under which both banks and corporations operate. Successful corporate debt workouts require proper incentives for both banks and borrowers to come to the negotiating table (Dado and Klingebiel 2000). The incentive framework for banks includes accounting, classification and provisioning rules, i.e., financial institutions need 
to be asked to realistically mark their assets to market. It also includes the legal and prudential frameworks. The prudential system needs to ensure that undercapitalized financial institutions are properly disciplined and closed. The insolvency system needs to enable financial institutions to enforce their claims against corporations, allow for speedy financial restructuring of corporations that are viable, and provide an efficient mechanism for the liquidation of enterprises that cannot be rehabilitated. A proper incentive structure also means limited ownership links between banks and corporations (since otherwise the same party could end up being both debtor and creditor).

A key component of a proper incentive framework is adequately capitalized financial institutions, as financial institutions need to have the loss absorption capacity to engage in sustainable corporate restructuring. In a systemic crisis, capital will often have to come from the government through recapitalization. General experience, as also highlighted by the recent East Asia experience, suggests, however, that recapitalization of financial institutions need to be structured and managed adequately to limit moral hazard. In their analysis of 39 banking crises, Honohan and Klingebiel (2000) find that repeated, incomplete recapitalizations tend to increase the overall fiscal costs of resolving a banking crisis. One possible explanation is that marginally capitalized banks tend to engage in cosmetic corporate restructuring, such as maturity extension or interest rate reduction on loans to non-viable corporations, rather than debt write-offs. Besides adequate capitalization, preferably by private shareholders, banks' incentives to undertake restructuring can be strengthened by linking government financial resources directly to the actual financial corporate restructuring undertaken by banks. For example, a capital support scheme in which additional fiscal resources are linked to actual corporate restructuring through loss sharing arrangements can induce banks to conduct deeper restructuring. Regardless, especially in weak institutional settings, limits on the actions of marginally capitalized banks will typically be necessary.

In principle, the government should only capitalize or strengthen the capital base of those financial institutions with charter and franchise value. But, apart from political economy problems, it will often be difficult for the government to distinguish good from bad banks. Risks-sharing mechanisms with the private sector, such as co-financing arrangements with government equity infusion (in the forms of preferred shares) when the private sector provides capital, can help identify the better banks. This still requires some institutional framework to avoid misuse. Especially in a weak institutional environment with limited private capital, the literature suggests that governments may want to rely more on hard-budget constraints on weak banks, such as a $100 \%$ marginal reserve requirement on (new) deposits, to prevent a large leakage of fiscal resources, including through excessive guarantees on financial institutions' liabilities. And good banks may need to be actively coerced to receive support, as they may resist government interference. But, without some support, the risk is that the good banks cannot provide the necessary financial intermediation services to the corporate sector, thus aggravating the crisis. 


\section{Corporate sector restructuring}

The nature of a systemic crisis, and the already large links between the solvency and performance of the corporate and financial sectors in normal times, make it clear that bank restructuring needs to be complemented with corporate restructuring. To start the corporate restructuring process, a quick triage of corporations into operationally viable and not financially distressed corporations; operationally viable, but financially distressed corporations; and financially and operationally unviable corporations would be preferable. In a normal restructuring situation of an individual case of financial distress, private sector agents will undertake this triage and then start the necessary operational and financial restructuring. ${ }^{6}$ In a systemic crisis, however, case-by-case restructuring will be difficult, as the incentive framework under which agents operate is likely not conducive, private sector capital is typically limited, and coordination problems are large. ${ }^{7}$

The starting point nevertheless will have to be to have a proper incentive framework for private sector agents to allow and encourage market-based, sustainable corporate restructuring. Given that the crisis is likely in part induced by weaknesses in the environment under which the corporate sector previously operated, the first step for the government will have to be to create an enabling environment. Depending on the country circumstances, this can imply undertaking corporate governance reforms, improving the bankruptcy and other restructuring frameworks, enhancing the efficiency of the judicial system, liberalizing entry by foreign investors, changing the competitive framework for the real sector, or introducing other, supportive structural measures. In general, the political economy of reform suggests that a crisis can often be a time to get difficult structural reforms accepted, or at least initiated (Haggard, 2001).

Most crisis countries do undertake reforms to the incentive framework for restructuring (see Claessens et al. 2001, Klingebiel and Dado, 2000, Stone, 2000a and 2000b, and World Bank 2000, for different groups of crisis countries), although the strengths and depth of the reforms differ. For example, although its crisis started in the fall of 1997, Indonesia did not adopt a new bankruptcy regime to replace its pre-war II, Dutch code, until August 1998, 12 months after the crisis had started. Even then, there have been very few bankruptcy cases in Indonesia in the months following. In the case of Thailand, only on February 12, 1999 did the Senate of Thailand approve The Act for the Establishment of and Procedure for Bankruptcy Court, an act that was intended to increase the efficiency of judicial procedures in bankruptcy cases, although the financial crisis started on July 2 1997. Following the adoption of the act, the number of

\footnotetext{
${ }^{6}$ Financial restructuring for corporations can take many forms: reschedulings (extensions of maturities), lower interest rates, debt-for-equity swaps, debt forgiveness, indexing interest payments to earnings, and so on. Operational restructuring, an ongoing process, includes improvements in efficiency and management, reductions in staff and wages, assets sales (for example, reduction in subsidiaries), enhanced marketing efforts, and so on with the expectation of increased profitability and cash flow.

${ }^{7}$ For other papers on systemic corporate restructuring, include some specific case studies, see Claessens, Djankov and Mody, 2001.
} 
bankruptcies in Thailand still remained low, however, and fraught with difficulties (see further Foley, 2000).

Beyond fixing the environment, it can be necessary to create extra incentives for private sector agents for (quick) corporate restructuring. These incentives can involve tax, accounting or other measures. Banks, for example, may be given more leeway in obtaining tax relief from provisioning or restructuring loans. Corporations, for example, may be given more favorable accounting relief for the recognition of foreign exchange losses. In the wake of its crisis, Korea adopted such more favorable tax rules for corporate restructuring, although they ended up being more misused through cosmetic rather than real restructuring. Some countries have taken steps to offer guarantees on exchange rate behavior (for example, Indonesia with its so-called INDRA scheme and Mexico with its so-called FICORCA scheme; see further Stone, 2000b). These measures ought to be evaluated as to their efficiency from various perspectives-beneficial effects on restructuring, public finance, and possible redistributive effects. While they may speed up the recovery, for example, they often do not aid to fundamental reforms. In any case, the general opinion is that such measures should in principle be of a temporary, time-bound nature (i.e., with sunset clauses).

In addition, even when adequate for normal times, the (revamped) bankruptcy and restructuring framework might not be sufficient in case of a systemic crisis given the various coordination problems and weaknesses in other aspects of the institutional framework. Governments have therefore created special frameworks for corporate restructuring, such as the "London-approach"8 first used in Mexico (there called UCABE) and afterwards in several East Asian countries (Korea, Thailand, Malaysia and Indonesia). The London approach has involved an out-of-court accord, under regular contract or commercial law, to which all (or most) creditor institutions (are coerced to) sign on. With such an accord, agreements reached among the majority of creditors can often be enforced on other creditors without going through formal judicial procedures. Also, arbitration with specific deadlines, as well as specific penalties for failure to meet deadlines, can be made part of the accord, thus avoiding the formal judicial process to resolve disputes. ${ }^{9}$ The degree of such enhancements to the London approach has varied among countries. In East Asia, for example, the framework in Thailand, followed by those in Korea and Malaysia, were the most conducive to out-of-court restructuring, with the framework in Indonesia the least (Claessens et al. 2001). These differences appeared to explain in part the variations in the speed of restructuring in these four countries.

The most far-reaching proposal to enhance the framework for restructuring is that of "super-bankruptcy" (or "Super Chapter 11"), a temporary tool which allows corporate

\footnotetext{
${ }^{8}$ The London rules are principles for corporate reorganization first enunciated in the United Kingdom in the early 1990s. Since the London rules were not designed for systematic corporate distress, countries have tried to tighten them in various ways.

${ }^{9}$ Out-of-court negotiations and bankruptcy or other legal resolution techniques are not the only methods for dealing with financial distress. Economists have been proposing alternative procedures for some time. These center on versions of an asset sale or a cash auction. Cash auctions are easy to administer and do not rely on the judicial system (Hart et al., 1997). While attractive from a theoretical perspective, these proposals have not had recent followers, except for Mexico in 1998.
} 
management to stay in place automatically and forces debt-to-equity conversion (Stiglitz, 2001). Such a Super Chapter 11 can preserve the going concern value of firms by preventing too many liquidations and keeping in place existing managers, who arguable most often will know best how to run the firms. An important design issue is when to call for it, i.e., when is a crisis of a systemic nature, and who has the authority to call for such a suspension of payments? Political economy factors should be taken into account here as well, as some debtors could stand to gain disproportionately from a suspension of payments. So far, no country has adopted this approach. ${ }^{10}$

Even with an enhanced enabling environment, agents will likely not be able to triage corporations quickly and get the necessary restructuring underway. The resulting period of "deadlock" in claims or "debt overhang" can be especially risky in weak institutional environments and can greatly increase the costs to the public sector of finally resolving the crisis. Weak banks may continue to lend to "too big to fail" corporations, in part as a way of gambling for resurrection, and thus delay sustainable corporate restructuring. Owners of defunct enterprises may strip assets, leaving only shells of liabilities for creditors. Even financial viable corporations may stop paying promptly if faced with an insolvent banking system. It may then also be necessary in the short-run to use hard-budget constraints to limit the flow of resources to weak corporations coming from (weak) financial institutions or other sources of external financing. To further counterbalance tendencies of lending to weak corporations, thereby reducing credit to those corporations that can actually repay, it may also be necessary to temporarily have across-the-board mechanisms in place for certain classes of borrowers (SMEs) or certain activities (e.g., trade financing). The need for such "blunter" tools will increase with the degree of institutional weakness in the country. The "market-based" approach pursued in Indonesia for corporate restructuring, for example, seems to have had very little impact and probably only led to further asset stripping.

As a next step, it will often be necessary for the government to more directly support the corporate sector restructuring process. As with support for the financial system, it will be essential to restructure the strong and viable, and not the weak corporations. All too often, however, the unviable, e.g., "too big too fail' corporations, will be supported, rather than the deserving, operationally viable corporation. This was the case in Korea with the large chaebols, and in Indonesia and Thailand with the largefamily controlled conglomerates. These firms ended up receiving dis-proportioned large amounts of financing during the first phase of the crisis while smaller firms lacked even working capital (see Domac and Ferri 1999). The most difficult task is then also to choose the lead agent for corporate restructuring such that market-based incentives for a proper analysis of a corporation's prospects and durable operational and financial restructurings are preserved. This in turn requires a lead agent to undertake the restructuring.

\footnotetext{
${ }^{10}$ It should be noted, however, that while bankruptcy regimes differ considerably, even among developed countries, there is a general trend towards moving from more creditor-friendly regimes, that is liquidationoriented, to more debtor-friendly, that is more restructuring-oriented, regimes (see further Westbrook, 2001).
} 
The main choice for lead agent is between the government itself and the private sector in a decentralized way. The modalities for implementing this choice can be multiple. A centralized asset management corporation (AMC) will put the government in charge. A strategy of ex-ante recapitalization of privately owned banks will put the banks in charge. Under other models, investors and corporations themselves can become the lead agent, with the government sharing in the risks. The banks can work out nonperforming loans, for example, but with some stop-loss arrangements with the government. Or non-performing loans can be transferred to a number of corporate restructuring vehicles which, while state-owned, can be privately run by asset managers with some incentive stakes. Most important is that the lead agents have the necessary loss absorption capacity, as well as the institutional capacity, incentives and external enforcement mechanisms to effect the restructuring. Undercapitalized banks, for example, will not be very effective restructuring agents. And without a working bankruptcy regime, private agents will not be able to force recalcitrant debtors to come to the negotiating table, as has been the case in Indonesia and in Thailand, with the restructuring of Thai Petrochemical Industry which stretched out over three years the most notable example.

In practice, countries often choose a mixture of these various approaches when dealing with a systemic crisis. Of the four East Asian crises countries, for example, all eventually employed AMCs, all employed some form of out-of-court-systems for corporate restructuring; and most used, after some initial period, fiscal stimulus and monetary policy to foster economic growth. In addition, all enhanced, to varying degrees, their basic framework for private sector operations, including bankruptcy and corporate governance frameworks, liberalization of foreign entry in the financial and corporate sectors, etc. Success has varied, however, with the intensity in which these measures have been applied (Claessens et al., 2001). Similarly, both an AMC as well as a more decentralized approach were attempted in Mexico in 1995.

The empirical evidence on these mechanisms is limited, but tends to favor the more decentralized model. A review of seven centralized approaches using AMCs (Klingebiel 2000) shows that most AMCs did not achieve their stated objectives when it came to corporate restructuring. The paper starts with distinguishing corporate restructuring AMCs from bank rehabilitation AMCs. In two out of three cases, corporate restructuring AMCs did not achieve their narrow goals of expediting restructuring. Only the Swedish AMC successfully managed its portfolio, acting in some instances as lead agent in the restructuring process. Rapid asset disposition vehicles fared somewhat better with two out of four agencies, namely Spain and the US, achieving their objectives. The successful experiences suggest that AMCs can be effectively used, but only for narrowly defined purposes of resolving insolvent and unviable financial institutions and selling of their assets. But even achieving these objectives required many ingredients: a type of asset that is easily liquefiable (real estate), mostly professional management, political independence, a skilled resource base, appropriate funding, adequate bankruptcy and foreclosure laws, good information and management systems, and transparency in operations and processes. 
The evidence by Klingebiel on AMCs is corroborated by a review of three East Asian countries (Dado, 2000). The centralized AMC used in Indonesia and Korea did not appear set to achieve their narrow goal of expediting bank and/or corporate restructuring, while the AMC in Malaysia was relatively successful, helped by a strong bankruptcy regime in that country. When a mixture of approaches is tried, success has varied as well. In Mexico, neither the AMC nor the enhanced restructuring frameworks were effective, possibly because fundamental reforms were lacking (the bankruptcy regime in Mexico, for example, was not revamped until four years after this crisis). It appears to have been the export led-growth that led the Mexican recovery after 1995 (although it did not resolve its banking sector problems; see further Krueger and Tornell, 1999).

Dado and Klingebiel (2000) analyze the decentralized restructuring model for seven countries (Argentina, Chile, Hungary, Japan, Norway, Poland and Thailand). They find that the success of this approach depended on the quality of the institutional framework, including accounting and legal rules, and the initial conditions, including the capital positions of banks and ownership links. In Norway's case, for example, the government built on what were already favorable initial conditions to attain a solid overall framework for the decentralized approach. The biggest improvement to the overall framework was made in Chile's case, with favorable results. The experiences of Poland and Hungary ranked behind that of Chile, although Poland improved its overall framework much sooner than Hungary. Thailand made little progress with strengthening its framework. In Japan, despite many reforms to its overall framework, efforts remained blocked by large ownership links. And Argentina relied solely on public debt relief programs and did not change its overall framework for restructuring.

As the crisis can be a window to undertake structural reform, so can it be an opportunity to reform the ownership structure in the country. As a direct party to the restructuring process, the state will often become the owner of (defunct) financial institutions and corporations. As noted, this severely complicates the resolution of the crisis, as the government may not have the right incentives or capacity to effect the necessary operational restructuring and financial restructuring. At the same time, the large (in-)direct ownership by the state of the financial and corporate sectors provides for an opportunity to change ownership structures as part of restructuring process. This can have several benefits.

First, the changes can correct those ownership structures that were a contributing part to the crisis and thus help prevent future crises. To the extent, for example, that ownership concentration in the hand of a few families was a contributing factor to the crisis, as argued by some in the case of East Asia, the government can try to widen ownership structures. Second, the government can try to obtain political support for its restructuring by reallocating ownership. ${ }^{11}$ One option, for example, is to reprivatize financial institutions or corporations is such a way to favor redistribution of ownership

\footnotetext{
${ }^{11}$ Regardless of the changes in ownership and relationships between debtors and creditors, the government may want to create a special social safety net for the inevitable layoffs and help sustain political support for the restructuring process over the longer run. See further Levinsohn, Berry and Friedman in this volume for the case of Indonesia.
} 
among the general public or employees of the restructured institution. Another option would be to use some of the state-ownership to endow previously unfunded pension obligations from a pay-as-you-go system. In this way, the government can create ownership structures that over time will reinforce its reform strategies. Third, it can be a way to explicitly introduce third parties that have better incentives and skills in restructuring of individual corporations and determining financial relief. One specific option would to transfer non-performing loans to a fund jointly owned by private and public shareholders, but with the private stake being of lower seniority. Private shareholders in the fund would then face the right incentives when deciding on the financial viability of a corporation, but without having full formal ownership to the assets. Public resources would only be provided at the point when all parties-creditor banks, other creditors, new private investors, the government and the private shareholders in the fund-had reached agreement with the corporation.

Another common theme in the literature has been that corporate restructuring preferably happens within the context of overall supportive macro policies. The right stance of main macro-policies (fiscal and monetary) can help a speedy recovery of overall activity and corporate sector output. The appropriate fiscal stance has been extensively reviewed, especially in the context of the East Asian crisis (see also other papers in this conference). A review by IMF staff (Lane et al., 1999) suggests that the fiscal stance was too tight initially in East Asia. The appropriate monetary stance has been more controversial, and is still being debated (see Drazen, and West and Cho in this conference volume), but mainly with respect to the defense of the exchange rate. An important, although related, aspect is the effect on the corporate sector through a possible credit crunch.

Micro-based empirical literature suggests that there was some evidence of a credit crunch early during the East Asian crisis (Claessens, Djankov and $\mathrm{Xu}, 2000$, Colaco et al., 2000, Dollar and Hallward-Driemeier, 2000). The credit crunch was likely the result of both tighter capital adequacy requirements and the particular monetary policies being pursued. More generally, it has been found that, while the effects of tighter capital adequacy rules are minimal on aggregate credit provision, borrowers from weaker banks are affected by tighter regulation and supervision (BIS, 1999). Given the unbalanced financial systems in East Asia, where banks dominate and little alternative financing sources were available, and the fragile state of many banks even before the crisis (Claessens and Glaessner, 1997), it is likely that, at least initially, the banking sector weaknesses and tighter regulatory and supervisory frameworks led to a credit crunch for East Asian corporations (see further Domac and Ferri, 1999). Following this initial credit crunch, corporations may have ended up into a situation of debt overhang, with the consequent need for financial restructuring. 


\section{Additional empirical evidence on the effects of crisis resolution policies}

In this section, we try to shed more light on the costs and benefits of alternative crisis resolution policies. Specifically, we empirically investigate how policies affect the performance and financial structures of individual corporations. We focus on the corporate sector for several reasons. First, the final purpose of resolution policies, even if directed towards the financial sector only, is a revitalization of the real sector and overall economic growth. Using corporate sector indicators can thus provide a better measure of the final outcome. Second, the effects of policies can be more precisely measured by focusing on the corporate sector rather than the financial sector. The performance of banks, for example, will be highly affected by government financial actions, such as recapitalization, and therefore may not provide a good indication of the real outcomes achieved. Third, measuring the impact of resolution policies on a micro rather than a macro level (for example, by GDP) allows us to better differentiate across policies. We can control, for example, for country characteristics, such as different corporate sector structures, when studying policies commonly adopted.

We collect company-specific data for a sample of crisis countries around the period of crisis in each respective country. Our sample selection proceeded as follows. We collected company data from WorldScope for all emerging markets and developed countries that were classified by Caprio and Klingebiel (1999) as having had a systemic financial crisis. We had to exclude all crises prior to 1989 since WorldScope does not have sufficient data before 1989. We also had to exclude countries for which the crisis period is difficult to time, either because of multiple crises (such as in Argentina) or because the crisis stretches over a long period of time without clear peaks or ends (such as Japan). This left us with 17 countries with a systemic crisis. We had to further exclude some countries for which we did not have a significant number of corporations with available data. This set of excluded countries includes nine transition countries (Bulgaria, Czech Republic, Estonia, Hungary, Latvia, Lithuania, Poland, and Slovenia) and Venezuela. For Venezuela, for example, we only had 9 corporations for the whole sample period.

Given the data availability, we are left with eight crisis countries, namely Finland, Indonesia, South Korea, Malaysia, Mexico, Philippines, Sweden, and Thailand. For each country, we distinguish three periods. The crisis year is the year of the peak of the crisis as identified by Caprio and Klingebiel (1999). The pre-crisis year is defined as the average of the three years before the peak of the crisis and the post-crisis year as one year after the peak of the crisis. Table 2 reports the sample of crisis countries, and their respective crisis years.

In total, we have data company-specific data from WorldScope for 687 firms. The data could suffer from a bias if many sampled firms entered bankruptcy during the crisis years. For most countries, however, the set of firms is quite similar between pre- and post-crisis period. In fact, the data set includes more firms during the crisis year than 
during the pre-crisis year. ${ }^{12}$ This suggests that the data set does not suffer from a large survivorship or other reporting bias. The notable exception is the Republic of Korea for which the number of firms reporting in the post-crisis period is significantly less than those in the pre-crisis and crisis periods. The main reason is that at the date of data collection many Korean firms had not yet reported their financial statements for $1999 .{ }^{13}$

In estimating the impact of resolution policies on the performance of the corporate sectors, we distinguish between the depth of the crisis, the recovery after the crisis and the sustainability of the recovery. As a measure for the depth of the crisis, we use the difference in a corporation's operating income, defined as earnings before interest and taxes with depreciation added, as a ratio of sales, i.e., EBITDA-to-sales, between the precrisis and during-crisis period. Similarly, our measure for the degree of recovery of corporate performance is the difference in EBITDA-to-sales between the post-crisis and during-crisis period. And our measure for the sustainability of the recovery is the difference in EBITDA-to-sales between the post-crisis and pre-crisis periods.

Table 3 reports summary statistics of the company-specific data for EBITDA-tosales, interest coverage, leverage, debt composition (share of short term) and share of payables (trade) relative to total assets, the main variables used in the empirical analysis, across all countries. It is worth noting that the interest coverage figure (measured as operating income to interest payments) reflects both firm profitability and debt structure. We find that, measured by EBITDA-to-sales, firms performed the worst during the crisis year. Firms had a worse interest coverage during the crisis year than before and were more leveraged at the peak of the crisis than before the crisis. Firms generally reduced the share of short-term debt over the crisis period, while the share of trade debt was mostly unaffected by the crisis. We also find that, although both the performance and capital structure of firms improved after the peak of the crisis, firms did not reach precrisis performance levels and financing structures within two years after the peak of the crisis.

These general trends are also reflected in Figures 2 and 3 that plot respectively the EBITDA-to-sales and interest coverage ratios for the three periods. The earnings and interest coverage distributions shift to the left between the pre-crisis and the crisis period, and then recover somewhat, but not to the distribution before the crisis. When measuring performance and sustainability using other measures, similar results obtain. For example, the median operating return on assets falls from $5.5 \%$ in the pre-crisis period to $1.4 \%$ during the crisis period and then recovers to $2.8 \%$ in the post crisis period. And the median ratio of the market to book value of equity moves from 1.8 before the crisis period to 0.7 during the crisis period, to recover to only 1.03 in the post-crisis period.

\footnotetext{
${ }^{12}$ We have data on 990 firms for the pre-crisis years, 1,183 firms for the crisis years and 889 firms for the post-crisis years. In the regressions we use a balanced panel of 687 firms.

13 This reporting discrepancy may still result into a sample selection bias if, for example, late reporting is more common among unprofitable firms than among profitable firms. This would lead us to overestimate the recovery and the effects of any policies adopted on the speed of recovery.
} 
Table 3 also reports the summary statistics for individual countries for the same set of variables. The patterns for each country are generally the same as for the overall medians. Some exceptions are Finland, Indonesia, Mexico and Sweden, where postcrisis corporate sector performance is on average better than pre-crisis performance. In these countries, some corporations may have benefited from the depreciation of the exchange rate, explaining the better performance. This is not the case for the other countries: in Thailand, for example, post-crisis performance is actually the worst of all three periods. Korea and Malaysia correspond to the pattern for the whole sample, with the recovery performance above the crisis level, but below the pre-crisis level. In terms of interest coverage, the picture is more uniform across the countries: some deterioration during the crisis generally followed by an improvement. The exceptions are Malaysia and Thailand where the average interest coverage ratios decline throughout.

Apart from industry and other corporation specific factors, such as corporations' initial financial structures, differences in policies adopted may explain some of the differences. Our literature review, and in particular Honohan and Klingebiel (2000), motivate the specific policy measures we investigate. Honohan and Klingebiel identified for a large sample of countries those policy measures, which could be systematically linked to the fiscal costs of resolving a systemic crisis. The three specific policy variables we use from their analysis are: (1) whether the central bank has provided liquidity support to financial institutions during the crisis or not; (2) whether the government has guaranteed bank liabilities or not and (3) whether the government has established a publicly-owned, centralized asset management company or not. As noted in section 3, Honohan and Klingebiel show that these three measures particularly increased the overall fiscal costs of resolving a crisis, controlling for a number of country-specific factors. Since we investigate whether these policies resulted in improved performance and financial sustainability of the corporate sector, we can shed some light on whether a tradeoff might exist for certain policies between fiscal costs and corporate sector outcomes.

Table 4 presents the policy measures taken in the sampled countries. There are many similarities in policies across countries. Almost all countries' governments, for example, guaranteed the liabilities of the financial sector during the crisis, and only the Philippines did not. About half of the countries had extensive liquidity support to the financial sector and similarly about half did establish a public asset management corporation. The Philippines is the only country that did not undertake any of the three resolution measures. The correlation between the implementation of these policy measures is substantial, ${ }^{14}$ suggesting that they tend to be implemented as a package.

Given the limited number of countries in our sample and the fact that the policy measures are correlated, it is difficult to assess the impact of the implementation of each of the three policy variables in isolation and regression results from using individual policy dummies could be unreliable. We therefore create a composite policy index in our empirical work. This policy index, called "Policy", is simply defined as the sum of the

\footnotetext{
${ }^{14}$ The simple correlation between "liquidity support" and "guarantees" is $49 \%$, between "liquidity support" and "public AMC" $47 \%$ and between "guarantees" and "public AMC" $49 \%$.
} 
number of resolution measures taken to restore financial stability in the country. The three resolution measures considered include the provision of guarantees, liquidity support and the set-up of a public asset management company. The "Policy" variable thus ranges from zero to three. Table 5 shows the value for the Policy variable for the eight crisis countries.

As company-specific control variables, we use each corporation's initial leverage ratio (measured as total debt-to-assets), initial debt composition (measured as short-term debt-to-total debt), size (measured as the natural logarithm of sales), and use of trade debt (measured as payables-to-assets). To control for any sectoral differences across firms, we use industry dummies (based upon two-digit SIC codes) in the regressions.

Using these variables, we aim to answer the following questions. What are the effects of the announcement of these policies during the containment phase on firm performance and sustainability? Does the implementation of the set of resolution measures during the resolution phase of a crisis affect the speed of firm recovery? In addition to the resolution policies themselves, we also want to assess how certain firmspecific factors influence both the speed and the sustainability of the recovery of the corporate sector.

We use the following specific model to explain the depth of the crisis, as measured by the deterioration of firm profitability, the EBITDA-to-sales ratio (Model 1).

(1) $\frac{\text { EBITDA }}{\text { Sales }}($ pre - crisis $)-\frac{\text { EBITDA }}{\text { Sales }}($ crisis $)=$

\section{f(Policy index, Initial firm-specific variables (pre-crisis), Industry dummies).}

We use first differences, rather than percentage changes, because EBITDA-to-sales ratio can take on non-positive values. Given that the model is specified in first differences, and since we also control already for many firm specifics, we can ignore any fixed firm effects. With the "policy index" variable being our main focus, we also ignore any other changes in the macro environment. We therefore assume that, conditional on a crisis taking place, the effect of the implementation of the crisis resolution measures dominate all other changes in country-specific effects. While we include industry dummies in all regressions, these are not reported. In terms of firm-specifics, we expect that larger firms and firms with sounder debt structures suffer less from a crisis. We further expect that trade debt may act as an important substitute for bank financing during a crisis. Given that the number of observations per country differ, we estimate model 1 using both ordinary least squares (OLS) and weighted least squares (WLS) with weights related to the number of observations. All results are presented in Table 6 .

High firm profitability at the onset of the crisis is found to be strongly correlated with the depth of the crisis. Our interpretation is that the profitability of these firms rose to abnormally high levels until the onset of the crisis, possibly as a result of a credit boom preceding the crisis, and shortly thereafter experiences a sharp decline during the credit 
crunch. Larger firms are found to be less affected by the crisis than smaller firms. This may be because larger firms were more diversified and could absorb the shocks better. It could also be that banks renewed credit more easily for larger firms and stopped rolling over credits for small and not-well connected firms. We also find a sharper decline in corporate profitability for firms with larger shares of short-term debt, suggesting that such firms were affected by the increases in interest rates that occurred during the crisis period and were more exposed to the risks of bank not renewing credit lines. Furthermore, the regression results show that firms that depended more on trade debt were more affected. This suggests that firms themselves were also less willing to offer each other trade credit during a financial crisis. This could be because of a decreased ability of many debtors to repay the credit, or more generally, because of uncertainty on the financial health of firms. The finding on short-term and trade debt together suggest that firm which had healthier financing structures-lower debt-to-equity leverage and more long-term debt—managed the crisis better.

We do not find that the crisis resolution measures had any impact on reducing the drop in profitability in our sample of countries, as the coefficient on Policy is insignificant. One interpretation is that this set of crisis resolution measures are not sufficient or the right type of measures to stop the downfall in corporate profits. Another interpretation is that these measures can only be implemented past the peak of a crisis, making them ineffective to limit the decline. Either interpretation sheds doubt on the common policy advice to adopt these measures quickly.

We use the same type of regression model to explain the (relative) recovery of the profitability of firms (Model 2).

$$
\begin{aligned}
& \text { (2) } \frac{E B I T D A}{\text { Sales }}(\text { post }- \text { crisis })-\frac{E B I T D A}{\text { Sales }}(\text { crisis })= \\
& f\left(\frac{\text { EBITDA }}{\text { Sales }}(\text { pre-crisis })-\frac{\text { EBITDA }}{\text { Sales }}(\text { crisis }),\right. \text { Policy index, Initial firm-specific } \\
& \text { variables (pre-crisis }), \text { Industry dummies }) .
\end{aligned}
$$

We again use first differences because the EBITDA-to-sales ratio can take on nonpositive values. Compared to model 1 , the main difference in the regression setup is that we use the drop in firm profitability (the dependent variable in model 1) rather than the initial level of firm profitability as independent variable. This way we control for the possibility that profitability recovers more for firms that are hit more during the initial stage of the crisis. We estimate model 2 again using both OLS and WLS, with the results presented in Table 7.

We find that the recovery of firm profitability is strongly correlated with the decline in firm profitability during the initial stage of the crisis, suggesting a large meanreversion in firm profitability around the crisis period. However, firm profitability does not recover completely to its pre-crisis level, suggesting that it may take more than one year to recover from a crisis or that there is a permanent loss. The sharp recovery is in 
line with the results of Eichengreen and Rose (in this volume), Dooley and Verma (in this volume), and Lee and Park (in this volume) that the V-shaped recovery is the norm in currency crises. We also find that the recovery of larger firms is slightly better than those of smaller firms, suggesting that larger firms may be in a better position to absorb shocks as they are more diversified or because larger firms are politically better connected than smaller firms.

The other firm specific variables are generally not statistically significant, possibly as we already included firm-specific decline in profitability in the regression which has strong explanatory power. Surprisingly, however, firms' financing structures do not appear to affect recovery. This may reflect some offsetting effects. On one hand, more risky financing structures should make it more difficult for firms to obtain financing to resume their operations. On the other hand, there can be incentive effects from tighter financing situations. It has been found, for example, for a sample of U.S. firms that perform poorly for a year that higher predistress leverage increases the probability of operational restructuring, thus accelerating recovery (Ofek, 1993).

Interestingly, we find that the policy index is strongly correlated with the recovery in firm profitability. This suggests that the implementation of measures directed towards restoring the financial health of banks, such as removing non-performing loans from banks' balances sheet, have a positive spillover effect towards firms by increasing banks' ability to resume lending to more viable firms, thus accelerating the recovery of firms. The quantitative importance of the policy variable is significant. Firm profitability would have increased on average by around 10 percent if the country would implemented all three crisis resolution measures considered. ${ }^{15}$ Of course, these are simulated results for the average country and actual results will differ widely across countries. In Sweden, many loans were removed from banks' balance sheets and corporate sector performance recovered relatively quickly. This happened also in Indonesia, but the gains in corporate sector performance have been very limited, if any, so far, while the fiscal costs have been very large.

To assess the sustainability of the recovery, we investigate the factors influencing the difference in corporate performance after the crisis and before the crisis. We estimate the following model (Model 3).

(3) $\frac{\text { EBITDA }}{\text { Sales }}($ post - crisis $)-\frac{\text { EBITDA }}{\text { Sales }}($ pre - crisis $)=$

f(Policy index, Initial firm-specific variables (pre-crisis), Industry dummies).

Model 3 has the same explanatory variables as Model 1. The dependent variable tries to measure the lasting impact of the crisis on firm profitability. If the dependent variable is small, i.e., the firm's profitability has recovered to the level from before the

\footnotetext{
15 The average increase of around 10 percent equals the regression coefficient of the policy index variable in model 2 times three.
} 
crisis, then the recovery from the crisis can be thought to be sustainable. The regression results are presented in Table 8.

We find that firms with high profitability at the onset of the crisis do not recover fully over the crisis period to pre-crisis levels or profitability. This suggests that these firms had either unsustainable levels of firm profitability, possibly associated with a precrisis credit boom, or that it takes more than one year for firms to recover fully from a systemic crisis. We also find some evidence that firms with relatively large amounts of short-term debt before the crisis have greater difficulties to recover to their pre-crisis levels of firm profitability, possibly reflecting difficulties in resolving their financial distress. The other, firm-specific variables are not statistically significant.

We find that post-crisis levels of firm profitability are closer to their pre-crisis levels for firms in those countries that took (more) crisis resolution measures. According to the regression results, the simultaneous implementation of all three policy-measures under consideration would increase firm profitability by some 12 percentage points of sales.

The policy index being a composite index does not allow us to disentangle the different effects of the three policy measures on changes in firm profitability. ${ }^{16}$ Nevertheless we speculate that our findings are the results of two type of actions. The provision of liquidity support and the extension of unlimited guarantees both restore confidence in the financial system and indirectly help improve the performance of corporations. And the establishment of public asset management companies directly alleviates firms' financial conditions by removing non-performing loans of corporations from banks and granting financial relief. Of course, these measures come at (substantial) fiscal costs.

The regression results may suffer from a potential endogeneity problem if the implementation of the crisis resolution measures is more likely in countries with a deeper financial crisis. In this case there would be reverse causality between the dependent variable, "drop in EBITDA-to-sales", and the "policy" index variable. We performed some tests for the existence of this problem and did not find evidence that would suggest a major endogeneity problem in the regression results. Specifically, the policy index variable is not significantly correlated with the drop in EBITDA-to-sales between the precrisis period and the crisis period (the dependent variable in model 1), nor with the firms' initial debt structures (as measured by debt-to-total assets or short-term debt to total debt in the pre-crisis period). ${ }^{17}$ Also, an ordered probit or logit model with the policy index as dependent variable and the change in EBITDA-to-sales and debt structure indicators as

\footnotetext{
${ }^{16}$ We noted earlier that such an exercise would produce highly unreliable results because of the high correlation among the three policy measures and the limited number of countries in the sample. We therefore do not make this effort.

17 The correlation between the policy index variable and the difference in EBITDA-to-sales in the pre-crisis period and the crisis period is only 3\%; between the policy index variable and the initial debt-to-assets ratio $14 \%$ (but not significantly different from zero); and between the policy index variable and the initial shortterm debt-to-total debt ratio $11 \%$ (also not significantly different from zero).
} 
explanatory variables does not produce any significant results. This suggests that reverse causality is not a major problem.

As robustness on our dating of crises, we ran the same regressions in models 1 and 2 with a different crisis year, namely one year earlier than the crisis years reported in Table 2. We found results that are very similar to those reported in Tables 6 and 7. Again, we find that crisis resolution measures do not help to prevent the decline in firm profitability during the early stage of the crisis, but are effective (though costly) in terms of the recovery from a crisis. For ease of presentation we do not include these results.

\section{Conclusions}

The literature on systemic restructuring stresses the need for the government to actively intervene to overcome the many coordination problems in a systemic crisis and to relieve the shortage of financial capital, which both impede progress with case-by-case restructuring. The core issue to deal effectively with a systemic crisis then becomes how to resolve the coordination issues while preserving or enhancing incentives for normal market-based restructuring and transactions. This requires achieving a consistent set of government policies, both among issues and sectors, and over time.

The literature also stresses that fiscal and monetary policies have to support the recovery process in a systemic crisis. Supportive policies concern the need to strike the right balance between exchange rate support and avoiding a (too) serious credit crunch created by too high interest rates. Supportive policies also cover other dimensions, such as whether there should be any allowance made for automatic rollover of payments for small and medium enterprises during the early phases of a crisis, and the strictness of (new) capital adequacy requirements. As extensively debated in the context of the East Asian crisis, and earlier (for example, following the 1982 Chilean crisis), these supportive policies appear not always to have been in place during systemic crises.

Especially during the containment phase of a systemic crisis, but also afterwards, governments will have to balance achieving stability with aggravating moral hazard. One dimension is avoiding the extension of government guarantees of financial institutions' liabilities, which can create moral hazard and reduce the degree of freedom in future lossallocation. Another dimension is the closing or suspension of some financial institutions. While a tool to signal a certain supervisory stance and limit moral hazard, closing some financial institutions can conflict with the regaining of deposit confidence. In some systemic crises, when the institutional framework for bank resolution was weak and when there was much uncertainty among depositors and investors on the intrinsic value of the banking system, closing a (limited number of) banks without addressing the large problems in the financial system aggravated the systemic crisis.

In terms of financial reform, consistency concerns, among others, changes in prudential regulation in relation to the status of financial institutions' profitability and the availability of private capital. Capital adequacy requirements, for example, will need to 
be set consistent with current and future bank profitability and the availability of new, private capital. Raising capital adequacy requirements during a systemic crisis will often not be useful, as capital is negative, bank earnings are low or negative, and there is no or very limited new supply of capital. This also relates to public recapitalization and the fiscal envelope. Any public recapitalization of banks will have to take into the availability of fiscal resources. Several countries saw that the recapitalization of financial institutions with government bonds did not necessarily lead to a restoration of confidence as the final fiscal resources to back up these bonds were limited. A key, related intertemporal consistency issue in any crisis is the government's own credibility. We did not address this issue here directly, but it might be useful to note that credibility requires as a pre-condition, ex-ante consistency in many areas.

Finally, there needs to be consistency between the institutional development of a country and the realism of certain approaches. Clearly, institutional deficiencies can rule out certain approaches in some countries, although they may be best practice in other countries. These best practices can include, for example, a heavy reliance on a marketbased corporate restructuring approach—where banks are recapitalized and asked to workout debtors. But in an environment where corporate governance and financial system regulation and supervision are weak, this may be a recipe for asset stripping or looting, rather than sustainable restructuring. Clearly, from this context alone, emerging markets will need different approaches in systemic restructuring from developed countries.

While many of these lessons are often mentioned in the literature we review, this set of "best practice" policies appears not often to be applied. Often, in the middle of the crisis, "mistakes" may be made. Ex-post, it will be easier of course to point out these inconsistencies, but even ex-ante there have been enough clear cases where the design of the financial restructuring program had some inconsistencies. Most often, these inconsistencies will come about as policy makers are trying to overcome political constraints, and it thus becomes hard to judge whether they do this in the most efficient manner. At times, however, this may reflect genuine differences of opinion among policymakers or advisors on what constitutes best practice, as, for example, in the necessity to guarantee all liabilities during the initial phases of a crisis. The end result is similar, in the sense that consistency is often lacking.

Specific lessons from the empirical part of the paper reinforce some of the general lessons, and add new evidence to some that may be more controversial. The analysis on data of corporate sector performance suggests that a package of government guarantees on bank liabilities, the provision of liquidity support and the setup of public asset management companies help both the recovery and sustainability, but that these policies do not mitigate the depth of the crisis. Although the empirical results suggests that measures such as asset management companies can help in the short run, they may not provide the right incentives for banks and firms to improve firm capital structures in the long run. And for all measures, there will be a tradeoff, while they may speed up recovery, they also have been shown to increase fiscal cost. 
More generally, the final effect of government efforts at restructuring will need to take into account the political economy factors behind the causes of the crisis and its resolution. In this context, there might be possibilities actively to try to remap ownership structures in a systemic crisis such that recovery is speeded up and a more sustainable outcome results. Unfortunately, while we know little about systemic crises, we lack even more an understanding of the political economy of systemic crises. 


\section{References}

Baer, Herbert and Daniela Klingebiel, 1995, "Systematic Risk When Depositors Bear Losses: Five Case Studies", Research in Financial Services: Private and Public Policy, Volume 7, pages 195-302.

BIS (Bank for International Settlements). 1999. "Capital Requirement and Bank Behaviour: The Impact of the Basle Accord," Basle Committee on Banking Supervision Working Papers.

Bordo, Michael, Barry Eichengreen, Daniela Klingebiel and Maria Soledad MartinezPeria, 2001, "Is The Crisis Problem Growing More Severe?," mimeo, University of California, Berkeley, and Working Paper, World Bank, Washington, D.C.

Caprio, Jerry and Daniela Klingebiel, 1999, "Episodes of Systemic and Borderline Financial Crises", Mimeo, World Bank, October, Washington, D.C.

Claessens, Stijn and Thomas Glaessner, 1997, "Are Financial Sector Weaknesses Undermining the East Asian Miracle?," Directions in Development, World Bank, September.

Claessens, Stijn, Simeon Djankov and Lixin Colin Xu, 2000, "Corporate Performance in the East Asian Financial Crisis", World Bank Research Observer 15(1), 23-46.

Claessens, Stijn, Simeon Djankov and Daniela Klingebiel, 2001, "Financial Restructuring in East Asia: Halfway There?" in Resolution of Financial Distress (Stijn Claessens, Simeon Djankov, and Ashoka Mody, eds.), World Bank Institute, Washington, D.C.

Colaco, Francis, Hallward-Driemeier, Mary, and Dominique Dwor-Frecaut, 2000, "Asian Corporate Recovery: A Firm-Level Analysis," in Dominique Dwor-Frecaut, Francis Colaco and Mary Hallward-Driemeier (eds.), Asian Corporate Recovery: Findings from Firm-Level Surveys in Five Countries, World Bank, Washington, D.C.

Dado, Marinela, 2000, "Note on Centralized Asset Management Companies in Indonesia, Korea and Thailand", mimeo, World Bank, Washington, D.C.

Dado, Marinela and Daniela Klingebiel, 2000, "Decentralized, Creditor-Led Corporate Restructuring: Cross-Country Experience”, Mimeo, World Bank, Washington, D.C.

Dollar, David and Mary Hallward-Driemeier, 2000, "Crisis, Crisis, Adjustment, and Reform in Thailand's Industrial Firms," World Bank Research Observer, 15:1, February, $1-22$.

Domac, Ilker, and Giovanni Ferri, 1999, "The Credit Crunch in East Asia: Evidence from Field Findings on Bank Behavior", mimeo, World Bank, Washington, D.C. 
Edwards, Sebastian and Jeffrey Frankel (eds.), forthcoming, Currency Crises Prevention, NBER-conference/Chicago Press

Foley, Fritz, 2000, “Going Bust in Bangkok: Lessons from Bankruptcy Law Reform in Thailand," Harvard Business School, mimeo, January, Cambridge.

Haggard, Stephen, 2001 "The Political Economy of Financial Restructuring in East Asia," in Resolution of Financial Distress (Stijn Claessens, Simeon Djankov, and Ashoka Mody, eds.), World Bank Institute Washington, D.C.

Hart, Oliver, Rafael La Porta Drago, Florencio Lopez-de Silanes, and John Moore. 1997. "A New Bankruptcy Procedure that Uses Multiple Auctions," European Economic Review, 41:461-73.

Honohan, Patrick and Daniela Klingebiel, 2000, "Controlling the Fiscal Costs of Banking Crises", Policy Research Working Paper 2441, World Bank.

Klingebiel, Daniela, 2001, "The Role of Asset Management Companies in the Resolution of Banking Crises," in Resolution of Financial Distress (Stijn Claessens, Simeon Djankov, and Ashoka Mody, eds.), World Bank Institute, Washington, D.C.

Krueger, Anne, and Aaron Tornell, 1999, "The Role of Bank Restructuring in Recovering from Crises: Mexico 1995-98”, NBER Working Paper 7042.

Lane, Timothy, Atish Ghosh, Javier Hamann, Steven Phillips, Marianne SchultzeGhattas, and Tsidi Tsikata, 1999, "IMF-Supported Programs in Indonesia, Thailand and Korea,” IMF Occasional Paper No. 178, June 30, Washington, D.C.

Lindgren, Carl-Johan, Gillian Garcia, and Matthew I. Saal, 1996, Bank Soundness and Macroeconomic Policy, International Monetary Fund, Washington, D.C.

Lindgren, Carl-Johan, Tomás J.T. Baliño, Charles Enoch, Anne-Marie Gulde, Marc Quintyn, and Leslie Teo, 2000, "Financial Sector Crisis and Restructuring: Lessons From Asia", Occasional Paper 188, International Monetary Fund, January 21, Washington, D.C.

Ofek, E. 1993, "Capital Structure and Firm Response to Poor Performance: An Empirical Analysis," Journal of Financial Economics, 34 (1): 3-30, August.

Stone, Mark, 2000a, "Large-Scale Post-Crisis Corporate Sector Restructuring", Policy Discussion Paper 00/7, International Monetary Fund, Washington, D.C.

Stone, Mark, 2000b, "The Corporate Sector Dynamics of Systemic Financial Crises", Policy Discussion Paper 00/114, International Monetary Fund, Washington, D.C. 
Stiglitz, Joseph, 2001, "Bankruptcy Laws: Some Basic Economic Principles" in Resolution of Financial Distress (Stijn Claessens, Simeon Djankov, and Ashoka Mody, eds.), World Bank Institute, Washington, D.C.

Westbrook, Jay, 2001, "Systemic Corporate Distress: A Legal Perspective," in Resolution of Financial Distress (Stijn Claessens, Simeon Djankov, and Ashoka Mody, eds.), World Bank Institute, Washington, D.C.

World Bank, 2000, East Asia: Recovery and Beyond, Washington, D.C. 
Table 1: Patterns of Systemic Banking Crises

\begin{tabular}{llllllrl}
\hline Country & $\begin{array}{l}\text { Crisis } \\
\text { year }\end{array}$ & $\begin{array}{l}\text { Fiscal } \\
\text { cost }(\% \\
\text { of GDP) }\end{array}$ & $\begin{array}{l}\text { Peak } \\
\text { NPL } \\
\text { of loans) }\end{array}$ & $\begin{array}{l}\text { Real } \\
\text { GDP } \\
\text { growth }\end{array}$ & $\begin{array}{l}\text { Change in } \\
\text { exchange } \\
\text { rate }\end{array}$ & $\begin{array}{l}\text { Peak in real } \\
\text { interest } \\
\text { rates }\end{array}$ & $\begin{array}{l}\text { Decline in } \\
\text { real asset } \\
\text { prices }\end{array}$ \\
\hline Finland & 1992 & 11.0 & 13 & $-4.6 \%$ & $-5.5 \%$ & $14.3 \%$ & $-34.6 \%$ \\
Indonesia & 1998 & 50.0 & $65-75$ & $-15.4 \%$ & $-57.5 \%$ & $3.3 \%$ & $-78.5 \%$ \\
Korea & 1998 & 37.0 & $30-40$ & $-10.6 \%$ & $-28.8 \%$ & $21.6 \%$ & $-45.9 \%$ \\
Malaysia & 1998 & 16.4 & $25-35$ & $-12.7 \%$ & $-13.9 \%$ & $5.3 \%$ & $-79.9 \%$ \\
Mexico & 1995 & 19.3 & 29.8 & $-6.2 \%$ & $-39.8 \%$ & $24.7 \%$ & $-53.3 \%$ \\
Philippines & 1998 & 0.5 & 20 & $-0.8 \%$ & $-13.0 \%$ & $6.3 \%$ & $-67.2 \%$ \\
Sweden & 1992 & 4.0 & 18 & $-3.3 \%$ & $+1.0 \%$ & $79.2 \%$ & $-6.8 \%$ \\
Thailand & 1998 & 32.8 & 33 & $-5.4 \%$ & $-13.7 \%$ & $17.2 \%$ & $-77.4 \%$ \\
\hline
\end{tabular}

Data sources: "Crisis year" is the peak crisis year, from Caprio and Klingebiel (1999). The "fiscal costs as $\%$ of GDP" variable is from Honohan and Klingebiel (2000). The "peak non-performing loans as \% of total loans" variable is from Caprio and Klingebiel (1999) in the case of Indonesia, Korea, the Philippines and Thailand, Lindgren, Garcia and Saal (1996) in the case of Finland and Sweden, and Krueger and Tornell (1999) in the case of Mexico. The "real GDP growth" variable equals the percentage change in real fourthquarter GDP in the crisis year compared to real fourth-quarter GDP one year before the crisis year. CPI inflation is used to get the real growth in GDP, and the growth in GDP is in terms of local currency. GDP data are from IFS (IMF). The inflation rate equals the percentage change in the CPI during the crisis year and is from IFS. The "change in the exchange rate" equals the percentage change of the exchange rate versus the US dollar during the first quarter of the crisis year. An increase in the exchange rate indicates an appreciation. The exchange rate data are from IFS. The "real interest rate spike" equals the peak in the real money market rate during crisis year. For the Philippines, the real discount rate is reported instead of the money market rate, due to data unavailability. The interest rate data are from IFS. The "real growth in asset prices" variables is the largest drop on a monthly basis in the stock market index during the crisis year compared to the level of the stock market index in January of the year before the crisis year. The return is in local currency and corrected for inflation. We use the Datastream global market indices for Finland, Mexico and Sweden, and the IFC global market indices for the other countries. 
Table 2: Sample Crisis Countries and Crisis Years

\begin{tabular}{llll}
\hline Country & Pre-crisis & Peak of Crisis & Post-crisis \\
\hline Finland & 1989 & 1992 & 1993 \\
Indonesia & 1995 & 1998 & 1999 \\
S. Korea & 1995 & 1998 & 1999 \\
Malaysia & 1995 & 1998 & 1999 \\
Mexico & 1992 & 1995 & 1996 \\
Philippines & 1995 & 1998 & 1999 \\
Sweden & 1989 & 1992 & 1993 \\
Thailand & 1995 & 1998 & 1999 \\
\hline
\end{tabular}

Source: Caprio and Klingebiel (1999); authors' definitions. 
Table 3: Descriptive statistics

(means, with medians in brackets, and number of observations)

\begin{tabular}{|c|c|c|c|c|c|c|c|c|c|c|c|c|c|c|c|c|}
\hline \multirow[t]{2}{*}{ Country } & \multicolumn{3}{|c|}{ EBITDA/Sales } & \multicolumn{3}{|c|}{ Interest coverage } & \multicolumn{3}{|c|}{ Debt-to-assets } & \multicolumn{3}{|c|}{ Short-term debt/Total debt } & \multicolumn{3}{|c|}{ Payables/Total assets } & \multirow{2}{*}{$\begin{array}{c}\# \text { of } \\
\text { obs }\end{array}$} \\
\hline & e-crisis & Crisis & Post-crisis & Pre-crisis & Crisis & Post-crisis & Pre-crisis & Crisis & Post-crisis & Pre-crisis & Crisis & Post-crisis & Pre-crisis & Crisis & Post-crisis & \\
\hline \multirow[t]{2}{*}{ All } & 0.216 & 0.120 & 0.167 & 8.333 & 2.499 & 4.863 & 0.314 & 0.427 & 0.424 & 0.536 & 0.547 & 0.504 & 0.087 & 0.080 & 0.084 & 687 \\
\hline & {$[0.168]$} & {$[0.133]$} & [0.144] & [3.125] & [1.299] & [1.739] & [0.312] & {$[0.390]$} & [0.356] & [0.513] & {$[0.520]$} & [0.431] & {$[0.070]$} & {$[0.059]$} & 59] & \\
\hline \multirow{2}{*}{ Finland } & 0.129 & 0.136 & 57 & 2.272 & 1.697 & 3.184 & 0.370 & 0.432 & 0.409 & 0.253 & 0.259 & 0.281 & 0.092 & 0.086 & 0.092 & 67 \\
\hline & 07] & {$[0.122]$} & $1]$ & $1.587]$ & [1.266] & 24] & [0.357] & {$[0.412]$} & [0.398] & [0.207] & {$[0.242]$} & [0.237] & {$[0.070]$} & {$[0.055]$} & [0.059] & \\
\hline \multirow[t]{2}{*}{ Indonesia } & 0.256 & 0.089 & 0.292 & 9.813 & 2.942 & 9.785 & 0.323 & 0.595 & 0.503 & 0.652 & 0.710 & 0.552 & 0.097 & 0.079 & 0.076 & 54 \\
\hline & [0.226] & [0.153] & {$[0.274]$} & [3.448] & [0.645] & [2.500] & [0.329] & [0.609] & [0.493] & [0.746] & [0.969] & {$[0.422]$} & [0.057] & {$[0.046]$} & {$[0.038]$} & \\
\hline \multirow[t]{2}{*}{ Korea } & 0.162 & -0.029 & 0.170 & 2.235 & -0.274 & 2.125 & 0.481 & 0.566 & 0.668 & 0.505 & 0.569 & 0.463 & 0.110 & 0.092 & 0.110 & 50 \\
\hline & [0.140] & [0.119] & [0.141] & [1.515] & [1.053] & [1.852] & [0.453] & {$[0.450]$} & [0.390] & [0.495] & [0.590] & [0.414] & [0.100] & {$[0.083]$} & [0.066] & \\
\hline \multirow[t]{2}{*}{ Malaysia } & 0.226 & 0.008 & 0.122 & 16.848 & 4.061 & 5.187 & 0.212 & 0.386 & 0.390 & 0.667 & 0.630 & 0.647 & 0.075 & 0.066 & 0.067 & 180 \\
\hline & [0.181] & {$[0.130]$} & [0.146] & [6.667] & [1.333] & [1.120] & [0.192] & [0.299] & [0.299] & [0.762] & [0.624] & [0.676] & [0.051] & [0.041] & [0.045] & \\
\hline \multirow[t]{2}{*}{ Mexico } & 0.258 & 0.241 & 0.307 & 10.215 & 2.665 & 4.411 & 0.258 & 0.338 & 0.330 & 0.403 & 0.431 & 0.338 & 0.081 & 0.071 & 0.079 & 49 \\
\hline & [0.207] & {$[0.225]$} & {$[0.272]$} & [3.280] & [1.835] & [3.125] & [0.287] & [0.319] & [0.303] & [0.336] & {$[0.362]$} & [0.252] & {$[0.050]$} & {$[0.050]$} & [0.059] & \\
\hline \multirow[t]{2}{*}{ Philippines } & 0.337 & 0.186 & 0.215 & 7.661 & -1.908 & 2.681 & 0.258 & 0.319 & 0.320 & 0.567 & 0.505 & 0.451 & 0.104 & 0.102 & 0.098 & 46 \\
\hline & [0.271] & {$[0.175]$} & [0.175] & [4.348] & [0.799] & [1.282] & [0.272] & [0.296] & [0.335] & [0.495] & [0.466] & [0.321] & [0.090] & [0.074] & {$[0.072]$} & \\
\hline \multirow[t]{2}{*}{ Sweden } & 0.144 & 0.109 & 0.162 & 3.621 & 0.448 & 3.832 & 0.299 & 0.323 & 0.307 & 0.380 & 0.346 & 0.318 & 0.099 & 0.087 & 0.099 & 94 \\
\hline & [0.112] & [0.088] & [0.119] & [2.778] & [1.118] & [2.000] & [0.280] & [0.346] & [0.310] & [0.299] & [0.309] & [0.246] & [0.093] & {$[0.078]$} & {$[0.086]$} & \\
\hline \multirow[t]{2}{*}{ Thailand } & 0.247 & 0.255 & 0.130 & 6.304 & 4.222 & 5.840 & 0.406 & 0.504 & 0.507 & 0.619 & 0.689 & 0.635 & 0.078 & 0.080 & 0.084 & 147 \\
\hline & {$[0.200]$} & {$[0.200]$} & {$[0.130]$} & [3.226] & {$[2.222]$} & {$[0.952]$} & {$[0.411]$} & {$[0.532]$} & [0.509] & {$[0.651]$} & {$[0.777]$} & [0.693] & {$[0.059]$} & {$[0.053]$} & {$[0.059]$} & \\
\hline
\end{tabular}

Source: WorldScope. 


\section{Table 4: Resolution policies across sampled countries}

\begin{tabular}{lll}
\hline & Yes & No \\
\hline Guarantee & Finland, Indonesia, Korea, & Philippines (1) \\
& Malaysia, Mexico, Sweden, & \\
& Thailand (7) & \\
Liquidity support & Finland, Indonesia, Korea, & Malaysia, Philippines, \\
& Mexico, Thailand* (5) & Sweden (3) \\
Public AMC & Indonesia, Korea, Malaysia, & Finland, Philippines, \\
& Mexico (4) & Sweden, Thailand (4) \\
\hline
\end{tabular}

Notes: * indicates that liquidity support is provided to non-bank financial institutions only, not to deposit and money banks as well.

Source: Honohan and Klingebiel (2000).

Table 5: Policy index across crisis countries

\begin{tabular}{ll}
\hline Country & Policy Index \\
\hline Finland & 2 \\
Indonesia & 3 \\
S. Korea & 3 \\
Malaysia & 2 \\
Mexico & 3 \\
Philippines & 0 \\
Sweden & 1 \\
Thailand & 3 \\
\hline
\end{tabular}

Notes: The policy index is defined as the sum of the number of resolution measures taken to restore financial stability in the country. The three resolution measures considered include the provision of guarantees, liquidity support and the set-up of a public asset management company.

Source: Honohan and Klingebiel (1999); authors' calculations from Table 4. 


\section{Table 6: Depth of crisis: EBITDA/Sales}

\begin{tabular}{|l|r|r|}
\hline Variable & $(1)$ & $(2)$ \\
\hline Constant & .112 & .224 \\
\hline & $(.183)$ & $(.199)$ \\
\hline EBITDA/Sales pre-crisis & $* * .522$ & $* * * .531$ \\
\hline & $(.244)$ & $(.120)$ \\
\hline Sales & $*_{-} .018$ & $* * .024$ \\
\hline & $(.042)$ & $(.010)$ \\
\hline Payables & $* * .504$ & $* * .492$ \\
\hline & $(.255)$ & $(.208)$ \\
\hline Leverage & .079 & .147 \\
\hline & $(.089)$ & $(.097)$ \\
\hline Short-term debt & $* * * .228$ & $* * * .171$ \\
\hline & $(.053)$ & $(.059)$ \\
\hline Policy & .010 & .007 \\
\hline & $(.109)$ & $(.015)$ \\
\hline & & .133 \\
\hline Adjusted R-squared & .117 & 2.06 \\
\hline Durbin-Watson stat & 1.99 & 603 \\
\hline \# of observations & 603 & \\
\hline & & \\
\hline
\end{tabular}

Notes: Dependent variable is the difference between the EBITDA-to-sales ratio in the pre-crisis year and the EBITDA-to-sales ratio in the crisis year. "Pre-crisis EBITDA-to-sales pre-crisis" is the EBITDA-tosales ratio in the pre-crisis year. "Policy" is an index of policy measures directed towards restoring financial stability. It is the sum of three dummy variables. The first dummy variable takes value one if the government has issued an unlimited guarantee on bank liabilities, and zero otherwise. The second dummy variable takes value one if the government has provided open-ended liquidity support to financial institutions, and zero otherwise. The third dummy variable takes value one if the government has established a publicly-owned, centrally-managed asset management company, and zero otherwise. "Sales" is the natural logarithm of net sales in thousands of US dollars in the pre-crisis year. "Payables" is the payables-to-total assets ratio in the pre-crisis year. "Leverage" is the total debt-to-assets ratio in the precrisis year. "Short-term debt" is the short-term-to-total debt ratio in the pre-crisis year. We include industry dummies, but these are not reported. We report heteroskedasticity-corrected standard errors between brackets. Model (1) is estimated using ordinary least squares. Model (2) is estimated using weighted least squares with weights related to the number of country observations.

$*$ indicates significance at a $10 \%$ level. ** indicates significance at a $5 \%$ level. $* * *$ indicates significance at a $1 \%$ level. 


\section{Table 7: Recovery from a crisis: EBITDA/Sales}

\begin{tabular}{|l|r|r|}
\hline Variable & $(1)$ & $(2)$ \\
\hline Constant & $* *-.394$ & $* *-.293$ \\
\hline & $(.157)$ & $(.141)$ \\
\hline EBITDA/Sales drop & $* * * .772$ & $* * * .738$ \\
\hline & $(.138)$ & $(.062)$ \\
\hline Sales & $* .025$ & $* * .016$ \\
\hline & $(.014)$ & $(.008)$ \\
\hline Payables & $* * * .544$ & .154 \\
\hline & $(.171)$ & $(.151)$ \\
\hline Leverage & .044 & .054 \\
\hline & $(.095)$ & $(.064)$ \\
\hline Short-term debt & .050 & .035 \\
\hline & $(.058)$ & $(.038)$ \\
\hline Policy & $* * * .036$ & $* * * .041$ \\
\hline & $(.012)$ & $(.011)$ \\
\hline & & .541 \\
\hline Adjusted R-squared & .459 & 2.20 \\
\hline Durbin-Watson stat & 2.06 & 592 \\
\hline \# of observations & 592 & \\
\hline & & \\
\hline
\end{tabular}

Notes: Dependent variable is the difference between the EBITDA-to-sales ratio in the post-crisis year and the EBITDA-to-sales ratio in the crisis year. "EBITDA-to-sales drop" is the difference between the EBITDA-to-sales ratio in the pre-crisis year and the EBITDA-to-sales ratio in the crisis year. "Policy" is an index of policy measures directed towards restoring financial stability. It is the sum of three dummy variables. The first dummy variable takes value one if the government has issued an unlimited guarantee on bank liabilities, and zero otherwise. The second dummy variable takes value one if the government has provided open-ended liquidity support to financial institutions, and zero otherwise. The third dummy variable takes value one if the government has established a publicly-owned, centrally-managed asset management company, and zero otherwise. "Sales" is the natural logarithm of net sales in thousands of US dollars in the pre-crisis year. "Payables" is the payables-to-total assets ratio in the pre-crisis year. "Leverage" is the total debt-to-assets ratio in the pre-crisis year. "Short-term debt" is the short-term-to-total debt ratio in the pre-crisis year. We include industry dummies, but these are not reported. We report heteroskedasticity-corrected standard errors between brackets. Model (1) is estimated using ordinary least squares. Model (2) is estimated using weighted least squares with weights related to the number of country observations.

* indicates significance at a $10 \%$ level. ** indicates significance at a $5 \%$ level. $* * *$ indicates significance at a $1 \%$ level. 
Table 8: Sustainability: EBITDA/Sales

\begin{tabular}{|l|r|r|}
\hline Variable & $(1)$ & $(2)$ \\
\hline Constant & .095 & -.171 \\
\hline & $(.168)$ & $(.146)$ \\
\hline EBITDA/Sales pre-crisis & $* * *-.840$ & $* *-.565$ \\
\hline Sales & $(.127)$ & $(.117)$ \\
\hline & .006 & $* * * .019$ \\
\hline Payables & $(.012)$ & $(.007)$ \\
\hline & -.155 & -.233 \\
\hline Leverage & $(.151)$ & $(.159)$ \\
\hline & -.001 & -.007 \\
\hline Short-term debt & $(.076)$ & $(.063)$ \\
\hline & $*-.060$ & -.024 \\
\hline Policy & $(.032)$ & $(.039)$ \\
\hline & $* * * .040$ & $(.012)$ \\
\hline & $(.013)$ & .202 \\
\hline Adjusted R-squared & & 2.06 \\
\hline Durbin-Watson stat & .306 & 598 \\
\hline \# of observations & 1.96 & 598 \\
\hline & & \\
\hline
\end{tabular}

Notes: Dependent variable is the difference between the EBITDA-to-sales ratio in the post-crisis year and the EBITDA-to-sales ratio in the pre-crisis year. "EBITDA-to-sales pre-crisis" is the EBITDA-to-sales ratio in the pre-crisis year. "Policy" is an index of policy measures directed towards restoring financial stability. It is the sum of three dummy variables. The first dummy variable takes value one if the government has issued an unlimited guarantee on bank liabilities, and zero otherwise. The second dummy variable takes value one if the government has provided open-ended liquidity support to financial institutions, and zero otherwise. The third dummy variable takes value one if the government has established a publicly-owned, centrally-managed asset management company, and zero otherwise. "Sales" is the natural logarithm of net sales in thousands of US dollars in the pre-crisis year. "Payables" is the payables-to-total assets ratio in the pre-crisis year. "Leverage" is the total debt-to-assets ratio in the precrisis year. "Short-term debt" is the short-term-to-total debt ratio in the pre-crisis year. We include industry dummies, but these are not reported. We report heteroskedasticity-corrected standard errors between brackets. Model (1) is estimated using ordinary least squares. Model (2) is estimated using weighted least squares with weights related to the number of country observations.

* indicates significance at a $10 \%$ level. $* *$ indicates significance at a $5 \%$ level. *** indicates significance at a $1 \%$ level. 
Figure 1: Frequency of Systemic Banking Crises

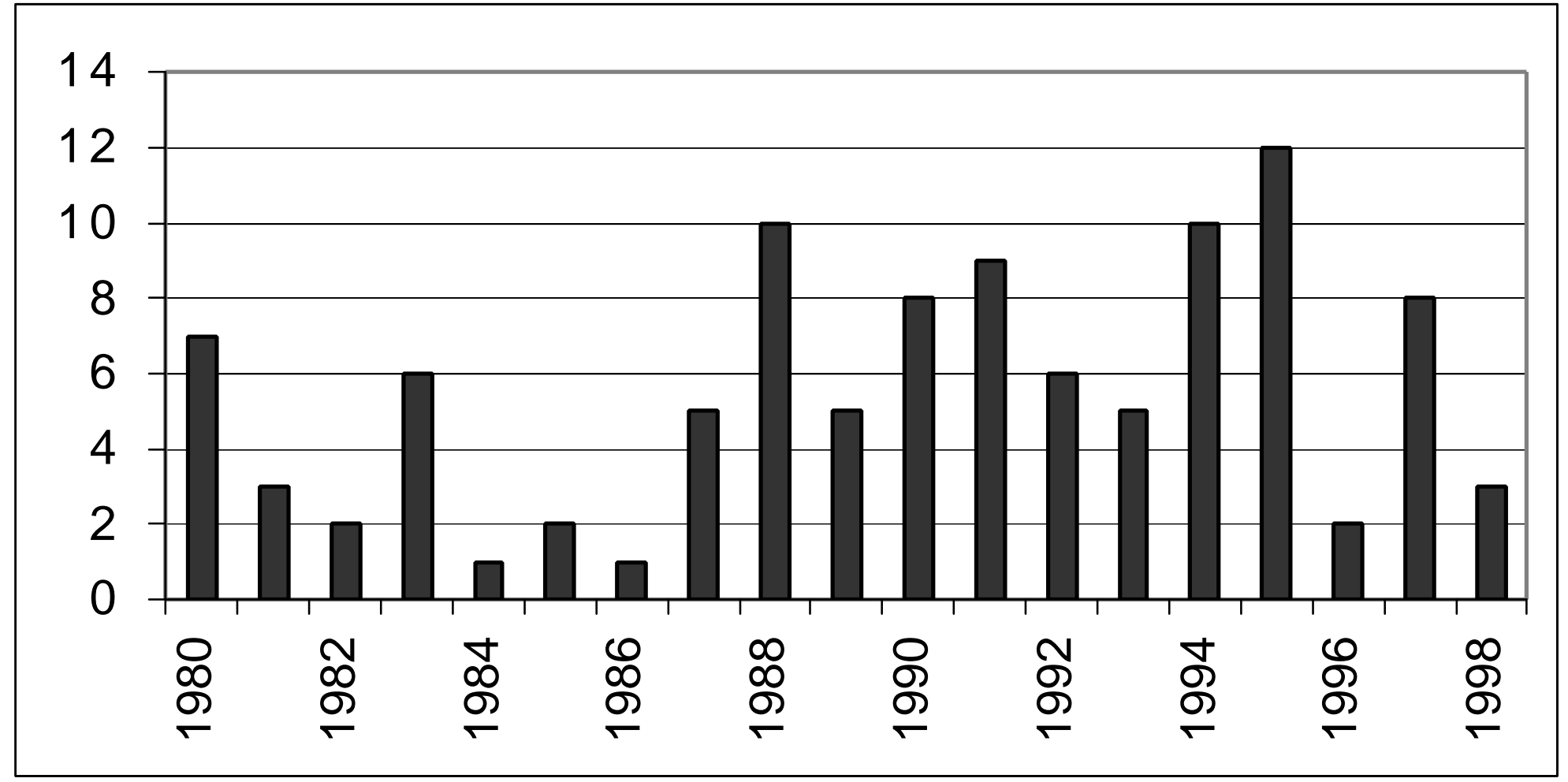

Notes: The frequency on the vertical axis indicates the number of countries that had a crisis starting in the year on the horizontal axis (total sample of crisis countries is 93).

Source: Caprio and Klingebiel (1999); authors' calculations. 


\section{Figure 2: EBITDA-to-sales across periods}

(fraction of firms)

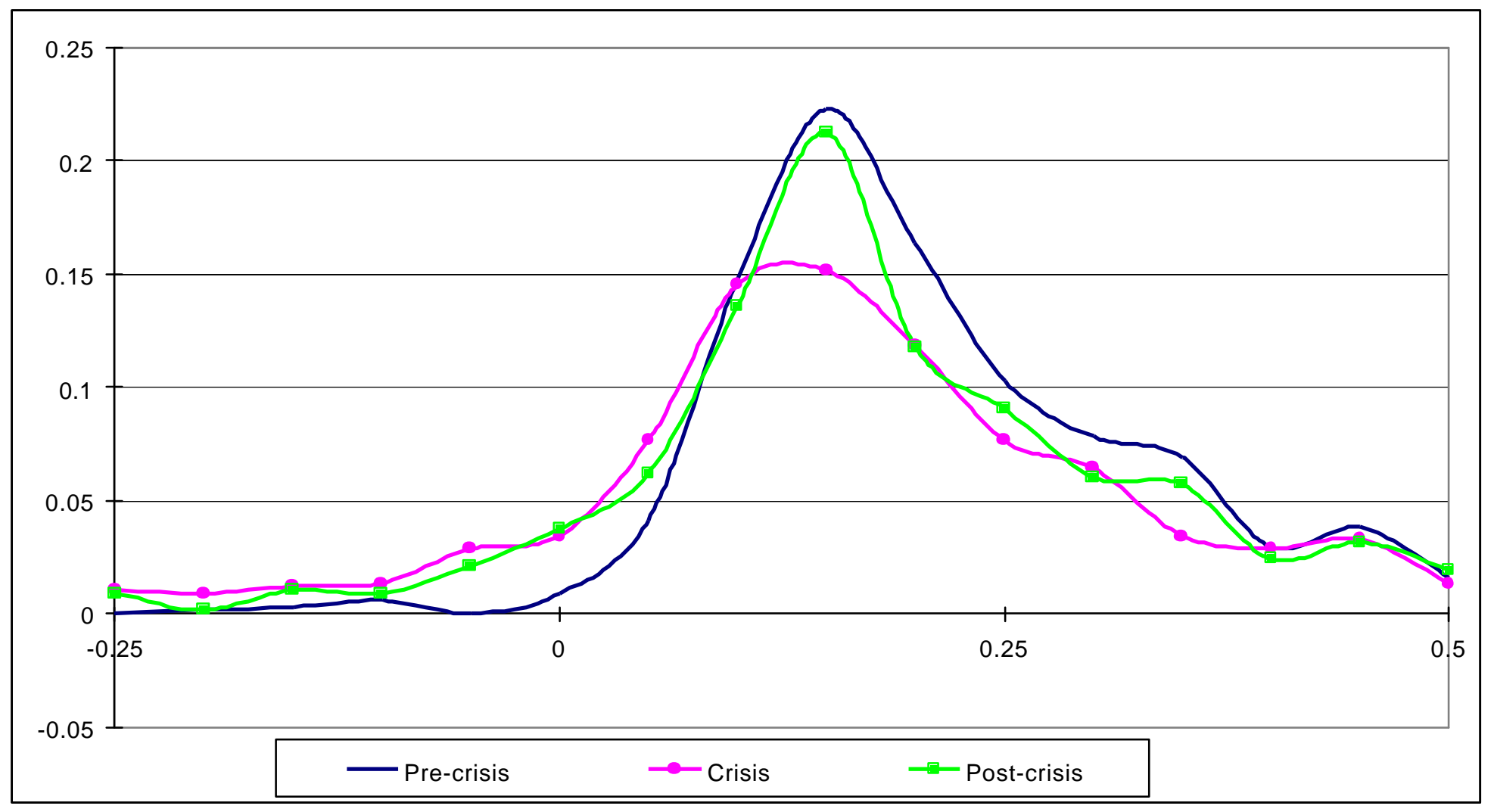

Notes: The sample includes firms from eight countries: Finland, Indonesia, South Korea, Malaysia, Mexico, Philippines, Sweden, and Thailand. The figure presents the distribution of EBITDA-to-sales averaged across all firms in the eight countries. The figure is smoothed. Source: WorldScope. 


\section{Figure 3: Interest coverage across periods (fraction of firms)}

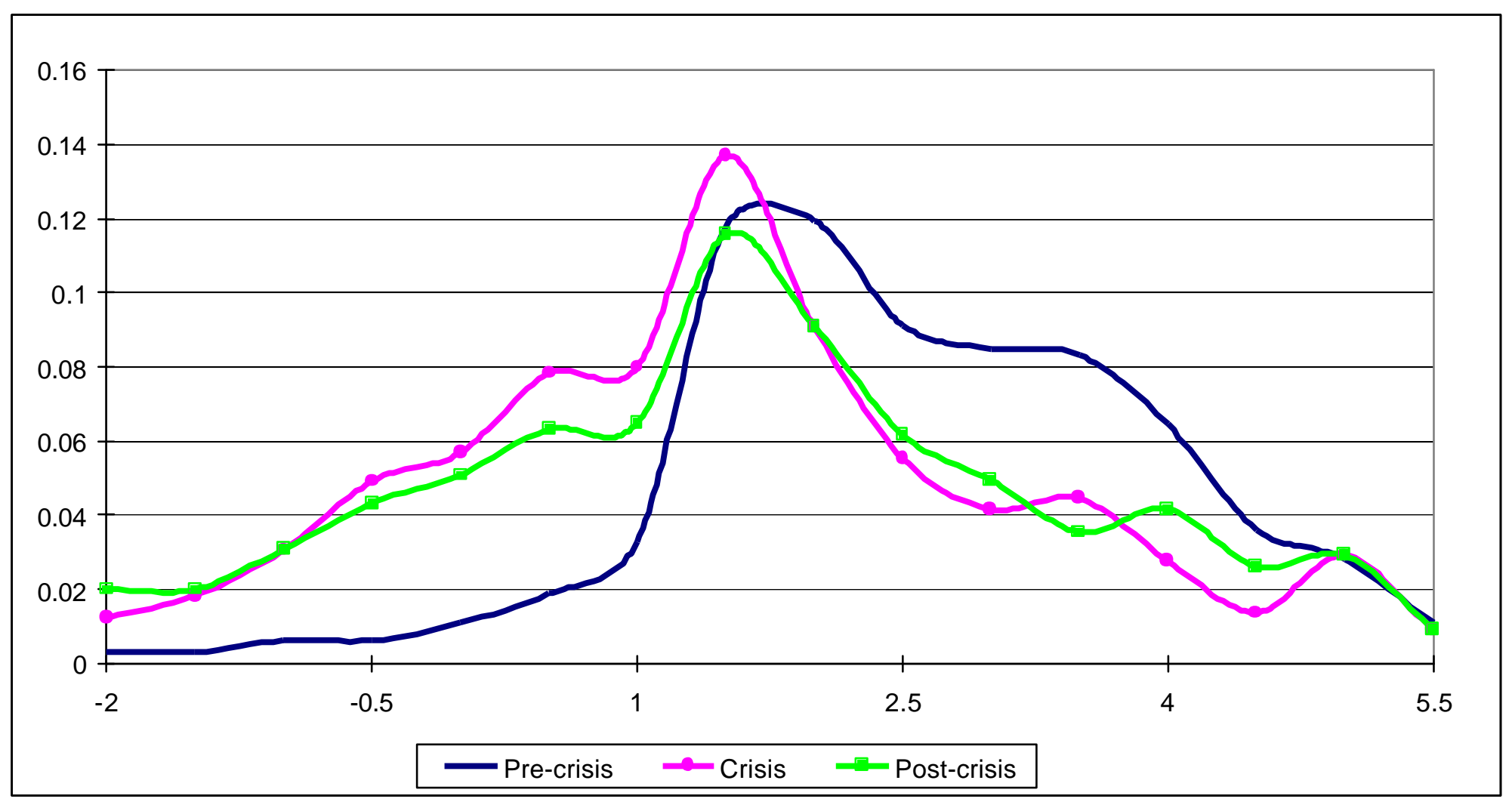

Notes: The sample includes eight countries: Finland, Indonesia, South Korea, Malaysia, Mexico, Philippines, Sweden, and Thailand. The figure presents the fraction of firms with specific interest rate coverage across all firms in the eight countries. The figure is smoothed. Source: WorldScope. 